\title{
Not to Worry, Vasișța Will Sort It Out: The Role of the Purohita in the Raghuvamsśa
}

\author{
Csaba Dezső
}

It is my greatest pleasure to dedicate this paper to Professor Alexis Sanderson, whose guidance I was fortunate to have during my doctoral studies at the University of Oxford. I couldn't have wished for a better supervisor. His formidable knowledge of the intellectual history of early-mediaeval India has been both overwhelming and inspiring right from the first lectures I attended. The reason why I hold that without the sound skills of philology it is pointless to undertake the study of the past is to a large extent thanks to the mastery he has shown in using those skills. The breadth of his learning and his keen interest in diverse aspects of classical Indian culture prevented me from ever feeling uncomfortable for not doing research on Śaivism, his main field, but persisting in studying $k \bar{a} v y a$. Our tutorials had a formative influence on my scholarship; they were always stimulating and eminently enjoyable. I am grateful to have had the good fortune of being his student.

Recounting the deeds of several kings of a royal lineage, Kālidāsa's epic does not describe a single hero's rise to success (abhyudaya). One could regard with Bonisoli-Alquati $(2008,105)$ the dynasty itself as the protagonist of the Raghuvamśa. There is one character, however, whose timely interventions help the continuance of the dynasty throughout the whole epic: this character is Vasiștha, the royal chaplain, purohita. But how is it possible that Vasiștha was the purohita and guru of the Sūryavamśa for so many generations? Is it the same Vasiștha?

A legend in the Taittirīya Sam hitā tells us that among the sages it was Vasiștha alone who could see Indra. The god taught him the Stomabhägas with the charge that any king who had him as purohita would thereby flourish if Vasiștha did not tell the Stomabhägas to other sages. "Therefore-teaches the text-one should have a descendant of Vasiṣtha (a Vāsiṣtha) as one's brahman priest."1 The

1 Taittirīya Saṃhitā 3.5.2.6: tásmād Vāsișțhó brahmá kāryàh. In the later Śatapatha Brāhmaṇa we read that formerly only a descendant of Vasisțha could become brahman, but now anyone who is suitable can (12.6.1.41, quoted in Minkowski 1991, 126). 
brahman was the priest who silently monitored the ritual. He was associated with the Atharvaveda and with the office of the family priest, the purohita of the patron of the sacrifice, the yajamanna. ${ }^{2}$ We may connect with these Vedic passages the tradition that Vasiștha or several Vasișthas were the purohita(s) of the kings of Ayodhyā, the members of the Ikșvāku- or Sūryavamiśa. Pargiter (1922, 203 ff.) distinguished seven Vasisthas in the legends, but, as he pointed out, these Vasișthas merged into one person. Thus we read in the Mahābhārata (1.164.9cd-11):

Ikșvākavo mahīpālā lebhire pṛthivìm imām. purohitavaram prāpya Vasiștham rșisattamam j̈ire kratubhiś cāpi nrpās te kurunandana. sa hi tān yājayām āsa sarvān nrpatisattamān brahmarșị̣ Pānḍ̂vaśreștha Bṛhaspatir ivāmarān.

The Ikșvāku kings conquered this world. Having obtained Vasisțha, the best of sages, as their excellent purohita, those kings performed sacrifices, $O$ descendant of the Kurus.

For that brahmin sage officiated for all those great kings at their sacrifices,

O best of the Pāṇạavas, as Bṛhaspati did for the gods.

In the Raghuvamśa, too, it is the same Vasiștha who is the purohita of the whole dynasty. As Dilīpa says to the priest (1.71cd): Ikșvākūnām durāpe 'rthe tvadadhīna hi siddhayah,, "For the successes of the Ikșvākus depend on you in goals that are hard to achieve." When Rāma returns from Lañā he also greets Vasiștha as the guru of the lineage of Ikșvāku (ikṣvākuvaṃśagurave praṇamya ..., 13.70).

Both Vedic and epic texts emphasise the purohita's role by the king's side in achieving victories and averting dangers. ${ }^{4}$ As Gonda $(1975,322)$ has shown, this protective function is already expressed by the name of the office: puro hita means "placed in front," that is in front of the king like a shield. In the Aitareya Brāhmana we read that "the gods do not eat the food of that king

2 Cf. Pañcaviṃśa Brāhmaṇa 12.8.6: annaṃ vai brahmaṇah purodhā, "the office of the purohita is the food of the brahman."

3 I quote the verses of Raghuvamśa 1-6 from Goodall and Isaacson 2003, and the verses of cantos 7-19 from Nandargikar 1982, unless indicated otherwise.

4 Gonda 1975 passim, Gonda 1956, 150 ff. 
who has no purohita," ${ }^{5}$ and "the purohita is half of the kșatriya's self,"6 he is the protector of the kingdom, rästragopa. ${ }^{7}$ This close relationship between king and chaplain and their co-operation in the protection of the state is expressed in a verse of the Raghuvamśa in which Kālidāsa writes about king Atithi (17.38):

Vasișthasya guror mantrāh sāyakās tasya dhanvinaḥ kiṃ tat sādhyam yad ubhaye sādhayeyur na sañgatāh??

The mantras of Vasisthha, the guru, and the arrows of that archerwhat is there to achieve that these two could not achieve when united?

According to the Arthaśāstra the purohita had a central place among the king's closest advisers. The ninth chapter of its first book gives us some details about the person of the royal chaplain (1.9.9-10):

purohitam uditoditakulaśllaṃ sāñge vede daive nimitte daṇdanītyāṃ cābhivinītam āpadām daivamānușin̄ām atharvabhir upāyaiś ca pratikartäram kurvīta.

tam ācāryaṃ śisyah pitaraṃ putro bhrtyaḥ svāminam iva cānuvarteta.

He should appoint as chaplain a man who comes from a very distinguished family and has an equally distinguished character, who is thoroughly trained in the Veda together with the limbs, in divine omens, and in government, and who could counteract divine and human adversities through Atharvan means.

He should follow him as a pupil his teacher, a son his father, and a servant his master.

trans. OLIVELLE 2O13, 74

When Dilipa visits Vasiștha in his ashram he extolls the merits of the purohita in preserving the welfare of the kingdom. Vasisțha is the one who "counteracts

5 Aitareya Brāhmaṇa 8.24.2: na ha vā apurohitasya rājño devā annam adanti (quoted in Gonda 1975, 320).

6 Aitareya Brāhmaṇa 7.26.4: ardhātmo ha vā eșa kṣatriyasya yat purohitaḥ (quoted in Gonda 1975, 320.)

7 Aitareya Brāhmaṇa 8.25.2 (quoted in Gonda 1975, 332). 
both divine and human calamities."8 The Arthaśāstra lists eight divine disasters (4.3.1): fire, water, famine, rats, harmful animals, snakes and demons. In another passage (8.4.1) it mentions fire, flood, disease, famine and epidemic. The mantras and rituals of the Atharvaveda and thus the purohita who was an expert in Atharvavedic rituals had major roles in averting these calamities. ${ }^{9}$ Vasiștha's "holy spells defeat the enemy even from a distance,"10 and "his offering thrown into the fire becomes rain for the crops parched by drought." ${ }^{\prime 1}$ It is the sacred power (brahmavarcasa) of the purohita thanks to which diseases and other disasters avoid the people (1.63). The king attributes the welfare and safety of his country to his guru (1.64):

tad evaṃ cintyamānasya guruṇa Brahmayoninā sānubandhāh kathaṃ na syuḥ sampado me nirāpadaḥ?

Therefore when my guru, who was born from Brahmā, takes care of me in this way,

how could my accomplishments not be continuous, free from calamities?

Vasiștha, who is well-versed in yoga, discovers with the help of concentration what causes Dilippa's childlessness: once he failed to salute Surabhi, the sacred cow, who cursed the king, at least in some versions of the texts. In another version it is the king's negligence in itself that made him childless. ${ }^{12}$ Luckily the grandchild of Surabhi is in Vasisțha's ashram, so the king can wait on her to obtain her blessing. As soon as her name has been uttered the holy cow appears: a good omen according to the sage, who is also an expert in the interpretation of signs, as a purohita should indeed be.

In the eleventh sarga Daśaratha is on his way back from the court of the king of Mithilā, where they have celebrated the weddings of his sons, when he encounters ominous signs: strong headwinds tear the flags of his army, a frightening circle surrounds the sun, the points of the compass filled with red clouds

8 Raghuvamśa 1.6o: daivīnām mānușin̄ām ca pratikartā tvam āpadām, cf. Ayyar 1925, 8.

9 Arthaśästra 9.7.84 prescribes the rites of the Atharvaveda against too much or too little rain, and against demons, 4.3.40 also against demons, while 4.3.35 against snakes. On the association of the purohita with the Atharvavedic tradition see Sanderson 2007, 204f., notes 28 and 29 .

10 Raghuvamśa 1.61: mantrair dūrāt samyamitāribhị̣.

11 Raghuvaṃśa 1.62: havir āvarjitam ... vrșțībhavati sasyānām avagrahaviśoșitām.

12 On these variants see Dezső 2014, $163 \mathrm{f}$. 
resemble a menstruating woman, and female jackals are howling. ${ }^{13}$ Daśaratha asks for Vasișțha's help (11.61 in Vallabhadeva's text):14

tat pratīpapavanādi vaikṛtaṃ kșipraśāntam adhikrtya krtyavit anvayuñkta gurum iśvaraḥ kṣiteh svantam ity alaghayat sa tadvyathām.

The king who knew what to do asked his guru about those portents like the headwind etc.,

if they would be averted soon, and he removed his fears saying, "It will end well."

The southern commentators (Mallinātha, Arunagirinātha and Hemādri) read the second pāda as preksya śantim adhikrtya (v. 62 in their version), that is Daśaratha asks the purohita about the pacifying ritual that quells the ills. Vasiștha's reply, "it will end well," might mean in this case that there is no need to perform such a ritual. The omens indicate the arrival of Paraśurāma, who is defeated by Rāma, so the story does indeed end well. ${ }^{15}$

The purohita performed such important ceremonies for the royal family as the rituals associated with childbirth. As we read in the Arthaśāstra (1.17.26): prajātāyāh putrasaṃskāram purohitạ kuryāt, "When she (i.e. the queen) has delivered, the chaplain should perform the rite of passage for the son" (trans. Olivelle 2013, 89). As Olivelle $(2013,486)$ remarks, this may also refer to the rites of early childhood, possibly including the upanayana. In the Raghuvamśa we see that Vasisțha performs the priestly duties when Dilīpa's son Raghu is born (3.18):

sa jātakarmany akhile tapasvinā tapovanād etya purodhasā krte Dilīpasūnur maṇir ākarodgatah prayuktasaṃskāra ivādhikaṃ babhau.

When the complete birth ritual was done by the ascetic chaplain who had come from the grove of ascetics,

Dilīpa's son shone yet more, like a precious stone taken from a mine and then polished.

13 Raghuvaṃśa 11.57-6o in Vallabhadeva's commentary, 58-61 in Mallinātha's.

14 Quoted from a draft edition prepared by Dominic Goodall, Harunaga Isaacson, Csaba Kiss, and myself.

15 The source of the story is Rāmāyaṇa 1.73.7 ff. 
In Kālidāsa's poetry, as Ingalls $(1976,19)$ has observed, ritual is associated with beauty. The purohita is like the jeweller who polishes the precious stone and transforms it into a gem. He performs the life-cycle rituals that make the individual a member of civilised society.

The purohita also had an important role in the marriage ceremonies of the royal families. Aja and Indumatī were wed by the chaplain of Indumatīs brother (7.20):

tatrārcito Bhojapateḥ purodhā hutvāgnim äjyādibhir agnikalpaḥ tam eva cādhāya vivāhasākșye vadhūvarau saṃgamayām cakāra.

There lord Bhoja's venerable chaplain, who was like fire, offered clarified butter and other things to the fire,

and having made the same [fire] witness to the marriage he wed the bride and the groom.

At the end of his life Raghu entrusted the kingdom to his son, Aja, and lived the life of a yogin, aiming for apavarga, liberation from the cycle of rebirths (8.16). He chose the time of his death himself: "by yogic meditation he reached the eternal Soul, beyond darkness" (tamasah param āpad aryayam purușam yogasamädhin $\bar{a}, 8.24)$. The verse describing Raghu's funeral ceremonies is transmitted in two versions. Vallabhadeva knew the following version (8.26):16

śrutadehavisarjanah pituś ciram aśrūṇi vișrjya Rāghavaḥ vitatāna samam purodhasā kratum antyam pṛthivišatakratoḥ. (8.26)

When he heard that his father had laid off his body, Raghu's son shed tears for a long time,

and then performed the final sacrifice of that Indra of the earth together with the chaplain.

The second half is transmitted in the southern commentaries as follows $(8.25 \mathrm{~cd}$ in Mallinātha, Aruṇagirinātha and Hemādri):

vidadhe vidhim asya naișthikaṃ yatibhị sārdham anagnim agnicit.

16 Quoted from a draft edition prepared by Dominic Goodall, Harunaga Isaacson, Csaba Kiss, and myself. 
... he, who had arranged the sacrificial fires, performed his last rites without fire together with the ascetics.

According to this version Raghu's body was not cremated but buried, as it was the custom in the case of sammyāsins, ascetics striving for final liberation. The purohita is not mentioned in this version; it was rather Raghu's fellow yogins who attended the ceremony. In the version known to Vallabhadeva it is not made explicit that the ritual was performed without fire, and Vasiștha, the purohita was also present. If we suppose that this was the original version, the text known to the later commentators might be the result of a correction or disambiguation: since Raghu had retired from secular life and was striving for mokșa as a renunciant, it might have seemed more correct to have his burial performed by the community of ascetics. ${ }^{17}$ However, the question might be more complicated, since in the variants of the verses describing Raghu's final years, as well as in the Keralan commentaries and that of Hemādri, we can detect a tendency to weed out or explain away references to Raghu being a samnyāsin. But in this verse, interestingly, it is the Southern commentators' version in which Raghu is clearly treated as a deceased yati. Raghu's position as a retired king was not without ambiguities: his son, Aja, did not allow him to retire to the forest, so Raghu moved to a place outside the palace, bahih kșitipālaveśmanah, at least in Vallabhadeva's version (8.14), ${ }^{18}$ because the Southern commentators knew a text according to which the old king moved outside the town, purād bahih. ${ }^{19}$ Here we perhaps see the same effort that tries to make Raghu's position less ambiguous and to move him further away from the palace and worldly life. But this effort is not completely successful since in the second half of the same verse we read that Śrī, the goddess of wealth and royal majesty, who was now enjoyed by his son, served Raghu like a daughter-in-law (samupāsyata putrabhogyayā snușayevāvikrtendriyah śriyā), which means that Raghu did not entirely live the life of an ascetic.

The king of the last canto of the epic, Agnivarna, lived a dissolute life and died of a consuming disease. His death was kept secret (19.54):

taṃ grhopavana eva saṃgatāḥ paścimakratuvidā purodhasā rogaśāntim apadiśya mantrinah sambhṛte śikhini gū ụham ādadhuh.

\footnotetext{
17 Thus Goodall 2001, 121.

18 8.14ab: sa bahịh kṣitipālaveśmano nivasann āvasathe yativratặ ... (Quoted from a draft edition prepared by Dominic Goodall, Harunaga Isaacson, Csaba Kiss, and myself.)

19 8.14ab: sa kilāśramam antyam āśrito nivasann āvasathe purād bahịh.
} 
The ministers joined by the chaplain who knew the last rites placed him on the pyre in secret

in the palace garden, under the pretext of a ceremony that averts disease.

The ministers and the purohita concealed the king's death because they wanted to secure the succession to the throne. Since Agnivarna did not have a son, they placed his pregnant widow on the throne, in accordance with the instructions of the Arthaśästra (5.6.36). ${ }^{20}$

The purohita had a central role in the ceremony of the royal consecration. About Aja we read the following in the Raghuvamiśa (8.3-4):

anubhūya Vasișthasaṃbhṛtaih salilais tasya mahābhișecanam viśadocchvasitena medin̄ kathayām āsa krtārthatām iva. sa babhūva durāsadaḥ parair guruṇātharvavidā kṛtakriyaḥ pavanāgnisamāgamo hy ayam sahitam brahma yad astratejasā.

Having experienced his great consecration with water gathered by Vasiștha, the earth seemed to express her contentment with clear sighs. When the ritual had been performed for him by the guru who knew the Atharvaveda, he became unassailable by his enemies, for when brahman is united with the power of weapons it is a union of wind and fire.

Both Arunagirinātha and Mallinātha quote ad loc. the Manusmṛti which teaches the inseparability of royal and priestly power $(9 \cdot 322):{ }^{21}$

nābrahma kṣatram ṛdhnoti nākșatraṃ brahma vardhate brahma kșatram ca sampṛtktam iha cāmutra vardhate.

The Kșatriya does not flourish without the Brahmin, and the Brahmin does not prosper without the Kșatriya;

but when Brahmin and Kșatriya are united, they prosper here and in the hereafter. trans. OLIVELLE 2OO5, 206

\footnotetext{
20 See Dezső 2014, 161f. Though many generations separate Raghu and Agnivarṇa, Vallabhadeva also identifies the purohita of the latter as Vasiștha (commentary to 19.54).

21 Cf. Ayyar 1925, 8.
} 
In the case of Atithi's consecration Kālidāsa stresses the importance of Atharvavedic mantras (17.13):

purohitapurogās taṃ jị̣num jaitrair atharvabhị

upacakramire pürvam abhișektum dvijätayah.

The brahmins headed by the chaplain began to consecrate him who was destined to victory

first with Atharvavedic mantras that lead to victory.

The rituals performed by the purohita made the king invincible in battle. When Raghu was about to set off to defeat Kuvera, the god of riches, Vasiștha empowered his chariot (5.27):

\section{Vasișthamantrokșaṇajāt prabhāvād udanvadākāśamahīdhareșu marutsakhasyeva balāhakasya gatir vijaghne na hi tadrathasya.}

Due to the power arisen from the sprinkling performed with mantras by Vasiștha

the course of his chariot was not blocked on the ocean, in the sky and in the mountains, like that of a cloud helped by the wind.

The source of the mantras used by the purohita was again probably the Atharvaveda. The ritual manual of the Kausikasūtra (15.11) contains several verses prescribed for the consecration of the chariot.

In the Raghuvamśa we see the purohita at every important ceremonial occasion taking place in the royal court, from the birth of the heir through the marriage of the prince to the funeral of the king. Vasisttha protected the king's person and made him invincible in battle with his Atharvavedic mantras. On the other hand Vasisțha was also the guru and adviser of the king who showed him the path to be followed: we see him in this role in the eighth canto when he comes to the support of the despairing Aja.

When a garland falling from the sky kills his wife, Aja laments over her with some of the most moving verses of Sanskrit literature. The only reason he does not throw himself on the funeral pyre is that people would speak badly of a king who follows a woman in death. Vasisțha learns in his ashram that Aja has been paralysed by grief, ${ }^{22}$ and since he is engaged in a ritual and therefore can-

22 abhiṣangajadam: 8.75 in Mallinātha, 76 in Hemādri, 73 in Aruṇagirinātha. Vallabhadeva reads abhișanginam (8.76). 
not visit the king personally he sends one of his disciples to convey Aja his message. Vasisțha knows everything that has happened, happens or will happen in heaven, on earth or in the netherworld, so he tells Aja in his message that Indumatî was a cursed apsaras who had to live in a human body until she was touched by a heavenly garland. Aja should stop grieving ( 8.84 in Vallabhadeva):23

\section{tad alạ̣ tadapāyacintayā vipad utpattimatām avasthitā}

vasudheyam avekṣyatām tvayā vasumatyā hi nrpāh kalatrinah.

So do not think about her death. Those who have been born will surely die.

Have regard for this Earth, for the Earth is the true wife of kings.

Vasiștha first expresses the truism we also find in the Bhagavadgitā, jātasya hi dhruvo mrtyuh, "death is certain for all that is born."24 Then he reminds Aja of his duty as a king: he must protect the earth, who, as the goddess Earth, is also his wife. This idea has already appeared in the same canto: Raghu handed over Aja the earth as a second Indumatī, and Aja took possession of the earth gently, as one enjoys a newly wedded wife (8.7). His divine wife gave him lots of gems, his human wife gave him a valorous son (8.28). But Aja's lament makes it clear whom he regards as his real wife (8.53 in Vallabhadeva): ${ }^{25}$

manasāpi na vipriyam mayā krtapūrvaṃ nanu kiṃ jahāsi mām vata śabdapatịn kṣiter ahạ̣ tvayi me bhāvanibandhanaṃ manah.

Surely I have not offended you even in my thoughts, why are you leaving me?

Truly I am the earth's husband only in name, my heart is bound with feelings to you.

If we consider Aja's words we might suspect that Vasiștha's admonition will not have much effect on him.

23 Quoted from a draft edition prepared by Dominic Goodall, Harunaga Isaacson, Csaba Kiss, and myself.

24 Bhagavadgītā 2.27, quoted by Vallabhadeva ad loc.

25 Quoted from a draft edition prepared by Dominic Goodall, Harunaga Isaacson, Csaba Kiss, and myself. 
The disciple continues Vasiștha's message as follows ( 8.85 in Vallabhadeva): ${ }^{26}$

udaye yad avāpyam ujjhatā śrutam āviṣkrtam ātmanas tvayā manasas tad upasthite jvare punar aklīvatayā prakāśyatām.

The learning that you showed when you avoided what could have been achieved in the time of success-

demonstrate the same again like a man now that your heart is suffering.

"What could have been achieved" (avāpyam) and what Aja avoided was, according to Vallabhadeva, ecstasy or being overjoyed ( praharșam madam $v \bar{a})$. As at the time of success he could stay away from an excessive mental state, in the same way he should behave like a man and be composed at the time of grief. ${ }^{27}$ Aja could not find Indumati even if he followed her in death, since those who live in the other world go on paths that differ according to their karma (8.86 in Vallabhadeva). Aja should stop crying because the tears of the relatives burn the departed souls (a belief we also read about in texts on dharmaśästra ${ }^{28}$ ). Then Vasiștha's message becomes more philosophical: ${ }^{29}$

maraṇam prakrtih śarīrịāạn vikrtir jīvitam ucyate budhaị. kșanam apy avatișthate śvasan yadi jantur nanu lābhavān asau. (8.88 in Vallabhadeva)

The wise say that death is the natural state of embodied creatures and life is a change in that state.

If a being remains breathing even for a moment it is surely fortunate.

avagacchati müḍhacetanah priyanāśạ̣ hrdi śalyam arpitam, itaras tu tad eva manyate kuśaladvāratayā samuddhrtam. (8.89 in Vallabhadeva)

26 Quoted from a draft edition prepared by Dominic Goodall, Harunaga Isaacson, Csaba Kiss, and myself.

27 Instead of yad avāpyam Mallinātha (8.84) and Aruṇagirinātha (8.82) read madavācyam, while Hemādri reads yad avācyam (8.85).

28 E.g. Yājñavalkyasmṛti 3, 11: śleṣmāśru bāndhavair muktạ̣ preto bhuñkte yato 'vaśaḥ | tasmān na roditavyam hi kriya kāryā prayatnatah \|, quoted by Vallabhadeva and Aruṇagirinātha ad loc.

29 Quoted from a draft edition prepared by Dominic Goodall, Harunaga Isaacson, Csaba Kiss, and myself. 
The foolish man regards the loss of his dear one as a dart shot into his heart.

Another man looks on the same as a dart that has been pulled out, for it is a door to beatitude.

svaśarīraśarīiṇ̄āv api smrtasaṃyogaviparyayau yadā virahạ̣ kam ivānutāpayed vada bāhyair vișayair vipaścitam? $(8,90$ in Vallabhadeva)

When we are taught that our own body and soul unite and then separate,

tell me which wise person should be tormented by separation from the external objects of the senses?

Death should be regarded as an unavoidable, natural event, which can even be beneficial: as Vallabhadeva says, when attachment ceases, one attains the imperishable state (snehakșayāt kila nirapāyapadāvāptih), the cutting of one's emotional bonds helps achieve the stopping of rebirth and redeath. Aja should regard his dead wife as one of the sense objects he meets and is parted from every day.

Finally Vasiștha appeals to Aja's pride: ${ }^{30}$

na prthagjanavac chuco vaśam vaśinām uttama gantum arhasi. drumasānumatoḥ kim antaraṃ yadi vāyau dvitaye pi te calāh?? (8.91 in Vallabhadeva)

Best of the self-controlled! You ought not to become subject to grief like common people.

What would be the difference between a tree and a mountain if both shook in the wind?

When Duṣyanta gives way to despair over the loss of Śakuntalā, the vidūṣaka expresses his puzzlement with similar words: "How have things got this far? How could the fortitude of good men be affected by grief? Surely mountains remain unshaken even by a storm wind."31 Duṣyanta is shaken up by Mātali,

30 Quoted from a draft edition prepared by Dominic Goodall, Harunaga Isaacson, Csaba Kiss, and myself.

31 Abhijñānaśákuntala 6, 103 (p. 278): kiṃ ṇedaṃ ìdisaṃ uvaṇadaṃ? kadā uṇa sappurisā soabaddhadiyyā honti? ṇaṃ pavādeṇa vi girīo ṇippakampā. Trans. Vasudeva 2006, 279. 
Indra's charioteer, who pretends to kidnap the vidūṣaka and thus arouses in the king his fighting spirit and his sense of duty to protect others.

Aja seemingly acquiesced in the words of his purohita, but, as Kālidāsa writes, Vasisțha's counsel "could not find a place in his heart full of grief and returned, as it were, to his guru" together with the disciple. ${ }^{32}$ The king took into consideration that his son was not yet of age and reigned eight more years, while his only solace was the likeness of his beloved (similarly to Dusyanta who found pleasure only in painting a portrait of Śakuntalā). When his heart was completely shattered by grief, Aja starved himself to death and left his body behind at the confluence of the Gangā and the Sarayū. Then he met his beloved again in Indra's heaven in a form that surpassed her former beauty.

We do not know what Kālidāsa's sources were for Aja's tragic story, but there is a work with which we can make interesting comparisons: Aśvaghoṣa's Buddhacarita. ${ }^{33}$ When prince Siddhārtha leaves the palace to live the life of a wandering ascetic in search of the teaching that gives liberation, the king's minister and purohita undertake to find him and appeal to his better self. Though they do not trust in the success of their undertaking, they set off nevertheless, setting off a battle between the bodhisattva and the diverse rules of scripture. ${ }^{34}$

Like in the Raghuvamiśa, we read about a message, but in the Buddhacarita it is the purohita who conveys the words of the king to his son, a king whose heart has been transfixed by the dart of grief. ${ }^{35}$ The king is inconsolable because Siddhārtha has not waited until his old age, as is prescribed in the śāstras, to retire to the forest in search of mokssa, and so his father could not transfer the kingdom to his son and retire himself (9.22). Only the coward needs such things as the forest and the symbols of ascetics (vanam ca lingam ca hi bhirucihnam, 9.18), for kings may also walk on the path leading to mokșa (9.20). The purohita tries to stir the bodhisattva's feelings and paints in vivid colours the sorrow he caused to his father, foster mother, wife, little son and the whole harem when he left the palace behind ( $9.23 \mathrm{ff}$.).

The bodhisattva, after some thought, replies that he had no other choice: because of the fear of sickness, old age and death he had to forsake his fam-

$32 \quad 8.92$ in Vallabhadeva: tad alabdhapadạ̣ hṛdiśskaghane pratiyātam ivāntikam asya guroh.

33 On the parallels between the works of Aśvaghoṣa and Kālidāsa see Gawronski 1914-1915; Johnston 1984, lxxxi; Nandargikar 1982, 161-196; and Tubb 2014.

34 Buddhacarita 8.85: yadi tu nrvara kārya eva yatnas tvaritam udāhara yāvad atra yāvaḥ| bahuvidham iha yuddham astu tāvat tava tanayasya vidheś ca tasya tasya. 
ily. ${ }^{36}$ Separation is unavoidable anyway, as in the case of travellers who meet on the way, therefore his father's clinging to him is pointless (9.33):

maddhetukaṃ yat tu narādhipasya śokaṃ bhavān āha, na tat priyam me, yat svapnabhūteșu samāgameșu saṃtapyate bhāvini viprayoge.

You spoke about the king's grief on account of me; I am not pleased that he is so distressed,

amidst associations as fleeting as dreams, when separation is bound to take place.

trans. OLIVELLE 2OO8, 257

Such ideas might be familiar from the Raghuvamśa where the purohita tries to shake up Aja with similar words, but without much success: during the remaining eight years of his life Aja consoles himself with the festivals of brief encounters with his wife in his dreams. ${ }^{37}$ While Aja out of a sense of duty does not throw away his life immediately and reigns until his son grows into a man, nothing and nobody can convince the bodhisattva to break his vow, return to the palace and take upon himself the burden of kingship, which he deplores. ${ }^{38}$

After the purohita the minister also tries to persuade the bodhisattva to return to the palace. He argues that we have no certain knowledge about the afterlife, so one should enjoy power and wealth as long as one can (9.53 ff.). Real liberation is the clearing of the three debts: towards one's ancestors by fathering offsprings, towards the gods by sacrificing and towards the sages by studying the Vedas (9.65). But the bodhisattva cannot be discouraged: for him there is no way back to the palace, and instead of a sceptical attitude he wants to acquire the knowledge leading to liberation himself (9.73).

The mission of the purohita in the Buddhacarita does not succeed; the bodhisattva is unwilling to leave the path he has chosen himself (9.78):

tad evam apy eva ravir mahīm pated, api sthiratvaṃ Himavān giris tyajet, adrștasattvo vișayonmukhendriyah śrayeya na tv eva grhān pṛthagjanah.

Therefore, although the sun may fall to earth, or Himālaya lose its fixity,

I'll not return home like a common man,

36 9.31: vyādhijarāvipadbhyo bhïtas tv agatyā svajanam tyajāmi.

37 Raghuvaṃśa 8.93: svapneșu kșaṇikasamāgamotsavaị.

38 Buddhacarita 9.40: mohāyatanam nrpatvam. 
whose senses yearn for sensual things, and who has not perceived the truth.

trans. OLIVELLE 2OO8, 275

Siddhārtha does not want to live the life of a common man, a life into which the purohita and the minister want to pull him back. For him separation from his loved ones is indeed the door leading to liberation. Vasisțha asks Aja to rise above common people and not to let his feelings take hold of him. Aja should accept what cannot be avoided; he should not grieve because of separation that is bound to happen, but he is unable to do this. Siddhārtha has recognised the impermanence of human relations and he is not shaken by appeals to family bonds.

The bodhisattva is more than human; his firm resolution to break away from the values of brahmanical society inspires awe. Aja remains very much human in his grief. Vasiștha demands of him detachment while remaining in the world: a way of life that Vasiștha himself, an ascetic sage who is at the same time a royal chaplain, lives. Vasisțha is truly the purohita of the dynasty and the dynasty needs kings who rule in an exemplary fashion, beget offspring and transfer the kingship to a suitable heir when the time has come. He saves the dynasty again since the transfer of power between Aja and his son Daśaratha takes place smoothly, but he fails to have any influence on Aja's feelings. Here we touch upon one of the key issues of Kālidāsa's poetry: the difficulty of creating and maintaining a harmony of duties, interests, and emotions, be they love or grief. Aja's example shows that there is a grief so deeply felt that no teaching about detachment, no appeal to duty can assuage.

\section{Acknowledgements}

This research has been made possible by financial support from the European Research Council synergy project "Beyond Boundaries: Religion, Region, Language and the State," grant agreement no. 609823.

\section{References}

\section{Primary Sources}

Abhijñānaśäkuntala. Somadeva Vasudeva, ed., trans. The Recognition of Shakúntala by Kalidasa. Clay Sanskrit Library. New York: NYU Press \& JJC Foundation, 2006. Arthaśāstra. R.P. Kangle, ed. The Kauțilīya Arthaśāstra, Part I: A Critical Edition With 
a Glossary. Delhi: Motilal Banarsidass, 1988 (reprint of the second edition of 1969).

Aitareya Brāhmaṇa. Theodor Aufrecht, ed. Das Aitareya Brāhmaṇa. Mit Auszügen aus dem Commentare von Sāyaṇācārya und anderen Beilagen. Adolph Marcus: Bonn, 1879 .

Kauśikasūtra. Bloomfield, M. 189o. "The Kāuçika-Sūtra of the Atharva Veda, with Extracts from the Commentaries of Dārila and Keçava." Journal of the American Oriental Society 14: i-lxviii, 1-424.

Taittirīya Saṃhitā. A. Weber, ed. Die Taittirîya-Saṃhitâ. Leipzig: Brockhaus, 1871-1872.

Pañcaviṃśa Brāhmaṇa. Ānandachandra Vedāntavāgīśa, ed. Tāṇdya Mahābrāhmaṇa with the Commentary of Sāyaṇa Āchārya. Kolkata: Asiatic Society of Bengal, 18701874 .

Buddhacarita. E.H. Johnston, ed., trans. Aśvaghoșa's Buddhacarita, or Acts of the Buddha. Delhi: Motilal Banarsidass, 1984 (combined reprint of 1936)

Manusmrti. Patrick Olivelle, ed., trans. Manu's Code of Law. A Critical Edition and Translation of the Mānava-Dharmaśāstra. New York: Oxford University Press, 2005.

Mahābhārata. V.S. Sukthankar, ed. The Ādiparvan, Being the First Book of the Mahābhärata, the Great Epic of India, For the First Time Critically Edited. Poona, Bhandarkar Oriental Research Institute, 1933.

Raghuvamiśa with Arunagirinātha's commentary. K.A. Poduval, and C.K. Raman Nambiar, eds. Raghwvamsa by Mahakavi Kalidasa with Prakasika Commentary of Arunagirinatha \& Padarthadeepika Commentary of Narayana Panditha. 3 vols. Tripunithura: Sanskrit College Committee, 1959-1964.

Raghuvamiśa with Mallinātha's commentary. The Raghuvaṃśa of Kālidāsa With the Commentary of Mallinātha Edited with A Literal English Translation, Copious Notes in English Intermixed with Full Extracts, Elucidating the Text, from the Commentaries of Bhațta Hemādri, Cāritravardhana, Vallabha, Dinakaramiśra, Sumativijaya, Vijayagaṇi, Vijayānandasūri's Varacaraṇasevaka and Dharmameru, with Various Readings etc. etc., edited by G.R. Nandargikar, $5^{\text {th }}$ edition. Delhi: Motilal Banarsidass, 1982.

Raghuvamiśa with Vallabhadeva's commentary, sargas 1-6. Dominic Goodall and Harunaga Isaacson, eds. The Raghupañcikā of Vallabhadeva, Being the Earliest Commentary on the Raghuvamiśa of Kālidāsa. Vol. I. Groningen: Egbert Forsten, 2003.

Raghuvamśa with Vallabhadeva's commentary, sargas 7-19. Critical edition in progress by Cs. Dezső, D. Goodall, H. Isaacson, and Cs. Kiss.

Raghuvamiśa with Hemādri's commentary. R.P. Dwivedī, ed. Raghuvamíadarpaṇa: Raghuvamśa Commentary by Hemādri, Vol. 1. Patna: Kashiprasad Jayaswal Research Institute, 1973 . 


\section{Secondary Sources}

Ayyar, K.B. 1925. “A Study of Kālidāsa in Relation to Political Science." In Proceedings and Transactions of the Third Oriental Conference, December 22nd to 24th, 1924, Madras, 1-16. Madras: The Law Printing House.

Bonisoli-Alquati, A. 2008. Kālidāsa's Raghuvaṃśa: An Analysis. Dottorato di Ricerca in Studi Indologici e Tibetologici Ciclo XXI. Universita degli Studi di Torino.

Dezső, Cs. 2014. "'We do not fully understand the learned poet's intention in not composing a twentieth canto': Addiction as a Structuring Theme in the Raghuvamśa." South Asian Studies 30 (2): 159-172.

Gawronski, A. 1914-1915. "Gleanings from Aśvaghoșa's Buddhacarita." Rocznik Oryentalistyczny 1: 1-42.

Gonda, J. 1956. "Ancient Indian Kingship from the Religious Point of View (Continued).” Numen 3 (2): 122-155.

Gonda, J. 1975. "Purohita." In Selected Studies. Vol. II. Sanskrit Word Studies, edited by J. Gonda, 320-337. Leiden: Brill.

Goodall D. 2001. "bhūte 'àha' iti pramādāt: Firm Evidence for the Direction of Change Where Certain Verses of the Raghuvamśa are Variously Transmitted." Zeitschrift der Deutschen Morgenländischen Gesellschaft 151: 103-124.

Ingalls, D.H.H. 1976. "Kālidāsa and the Attitudes of the Golden Age." Journal of the American Oriental Society 96 (1): 15-26.

Minkowski, Ch.Z. 1991. Priesthood in Ancient India. A Study of the Maitrāvaruna Priest. Sammlung de Nobili vol. XVIII. Vienna: Institut für Indologie der Universität Wien.

Olivelle, P. 2008. Life of the Buddha by Ashvaghosha. Clay Sanskrit Library. New York: NYU Press \& JJC Foundation.

Olivelle, P. 2013. King, Governance, and Law in Ancient India. Kauțilya's Arthaśāstra. New York: Oxford University Press.

Pargiter, F.E. 1922. Ancient Indian Historical Tradition. London: Oxford University Press. Sanderson, A. 2007. "Atharvavedins in Tantric Territory. The Ärgirasakalpa Texts of the Oriya Paippalādins and their Connection with the Trika and the Kālīkula." In The Atharvaveda and its Paippalāda Śākhā: Historical and Philological Papers on a Vedic Tradition, edited by Arlo Griffiths and Annette Schmiedchen, 195-311. Aachen: Shaker Verlag.

Tubb, G. 2014. "Baking Umā." In Toward a History of Kārya Literature. Innovations and Turning Points, edited by Y. Bronner, D. Shulman, and G. Tubb, 71-85. New Delhi: Oxford University Press. 